\title{
Factors affecting farm growth intentions of family farms in mountain regions: Empiri- cal evidence for Central Switzerland
}

\author{
RobertHuber $^{\text {ab }}$ ChristianFlury $^{\text {bc }}$ RobertFinger $^{d}$ \\ ${ }^{a}$ Swiss Federal Institute for Forest, Snow and Landscape Research WSL, Switzerland \\ ${ }^{b}$ Flury \& Giuliani GmBH, Agrar- und Regionalwirtschaftliche Beratung, Zürich, Switzerland

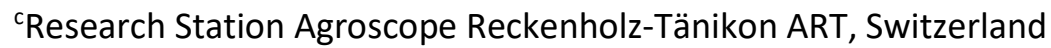 \\ dUniversity of Bonn, Production Economics Group, Germany
}

\section{Highlights}

-We study farmers' growth intentions using a combination of census and survey data.

- Farmers' preferences will impede a rapid structural change in the near future.

- Farm growth intention is not influenced by the perceived personal situation.

-Impact of policies supporting farm growth seems to be limited.

\begin{abstract}
Family farms in mountain regions are undergoing a progressive structural change and an ongoing shift in the allocation of production factors land, capital and labor. In Switzerland, various policy measures influence the re-allocation of these production factors. To understand the effectiveness of these schemes and to assess future farm structural change, it is useful to analyze the underlying drivers which support and hinder the emergence of individual farm growth strategies. We study the family farms' growth intentions using a logistic regression model based on a combination of census and survey data on family characteristics from two mountain case study regions in Central Switzerland. Factors supporting farm growth intentions are the relative change in farm size in recent years, farm related sunk costs, farm diversification and farm size. We found no support for the hypothesis that farm growth intention is also influenced by the perceived personal situation represented by indicators for the perceived workload, psychological stress and financial problems. In addition, off-farm labor did not prevent farmers from stating growth intentions. Our empirical findings suggest that (i) the most important factors which support farm growth intentions correspond with factors driving observed patterns of structural change; (ii) limited availability of family labor may result in a new critical threshold for farm growth strategies; (iii) aims and non-pecuniary preferences of farmers will impede a rapid structural change in the near future.
\end{abstract}

\section{Keywords}

Farm structural change; Farm survey; Logistic regression model; Agricultural policy; Swiss mountain region; Stated intentions 


\section{Introduction}

Farm structural change influences the productivity and efficiency of farming, income distribution within agriculture, demand for government services and infrastructure, and the well-being of local communities (Weiss, 1999). In most European regions, agriculture is undergoing a progressive structural change with a decline in the number of farms. These changes are particularly marked in mountain regions (Pinter and Kirner, 2014, Streifeneder et al., 2007) where small family farms are unable to withstand the pressure of competition from more favorable locations (Flury et al., 2013) and the provision of important ecosystem goods and services from agriculture is endangered (Huber et al., 2013). As a consequence, governments provide different forms of policy support to maintain a multifunctional agricultural sector in mountain areas. The importance of these policies is reflected by the goals of the latest policy reforms in the EU and Switzerland, in which more equitable and greener policy mechanisms designed to strengthen rural development and the provision of public goods (Mann and Lanz, 2013, Renwick et al., 2013).

In addition to empirical assessments of farm structural change (see e.g. Zimmermann et al., 2009 for a review), a series of recent studies explored the future intentions of farm households in reaction to policy reforms. Stated intentions are used to further the understanding of the impacts of policy on structural change by identifying determinants of farm structural changes as well as likely future changes (Barnes et al., 2014, Bartolini et al., 2012, Bartolini and Viaggi, 2013, Bougherara and Latruffe, 2010, Breen et al., 2005, Gorton et al., 2008, Latruffe et al., 2013, Lobley and Butler, 2010, Maye et al., 2009, O'Donnell et al., 2011, Raggi et al., 2013, Tranter et al., 2007). The use of survey data to enrich census data in the analysis of future structural change and its mechanisms has two important advantages. Firstly, stated intentions regarding future behavior complement model based assessments of future structural change with household characteristics and thus provide important information on the planning and allocation of budget resources (Breen et al., 2005, Latruffe et al., 2013, Pinter and Kirner, 2014). Secondly, farm household level surveys also permit the consideration of additional quantitative explanatory factors as well as qualitative issues thus enhancing our understanding of the mechanisms of reaction to policy. The understanding of the role of household characteristics provides insights into the functionality of the policy as well as a basis for the evaluation of its effectiveness (Bartolini and Viaggi, 2013, Breen et al., 2005, Viaggi et al., 2011). In addition, recent studies provide some evidence that despite the hypothetical nature of stated intentions, the emerging patterns can be, to some extent, aligned to ex-post behavior (Barnes et al., 2014, Gorton et al., 2008, Viira et al., 2014).

However, existing literature has not exploited the full potential of the combination of survey and census data sources, particularly with respect to two directions. Firstly, social factors affecting farm households' decisions with respect to farm growth have not been widely considered even though different authors claim that these factors are known to be decisive for farm-level decision-making (Bartoli and De Rosa, 2013, Celio et al., 2014, Darnhofer, 2015, Lobley and Butler, 2010, Weller et al., 2013). Secondly, links of survey and census data have focused on cross-sectional information. Thus, developments of the farms in the past have not been explicitly captured with census data. However, past developments are assumed to be relevant for current and future farm growth decisions, e.g. by indicating a development within the farm's life cycle (Calus et al., 2008, Latruffe et al., 2013, Weiss, 1999).

In this study, we aim to fill this gap by combining census data from different periods with surveys that also account for social factors influencing farm households. Our empirical analysis focuses on family farms in the Swiss Alps. In particular, we focus on farms in two cantons (Nidwalden, Uri) in the Central Swiss mountain region. We aim to improve the understanding of future farm structural change and the effect of policy measures supporting farm growth by presenting and discussing both economic and social factors that encourage or hinder intended farm growth in Swiss mountain regions. Thus, we investigate how, in addition to economic and structural factors, social factors such as perceived workload, psychological and financial stress constrain or support farmers' development strategies. In order 
to assess drivers of farm growth strategies, we address not only farm characteristics and economic and social resources, but also attitudes toward farm structural change and preferences for the development of these family farms in the near future. Furthermore, we explicitly include the observed changes in farm size as an explanatory variable in our analysis. The consideration of a wide set of factors determining farm growth intentions is essential for the development of effective policies designed to stimulate structural change.

Our focus on mountain agriculture in Switzerland is particularly relevant, due to the following two factors. Firstly, farm structural change is accentuated in mountain regions as many farms are very small and lack competitiveness (Flury et al., 2013). Thus, family farms often have significant income sources off the farm and limited labor availability which makes them vulnerable to policy changes. Secondly, mountain regions have a great potential to provide ecosystem goods and services of high societal and political relevance (Grêt-Regamey et al., 2012). Mountain agriculture provides, jointly with the production of food, a set of important goods and services such as landscape maintenance, biodiversity preservation and contributes to rural viability. Therefore, Swiss agricultural and regional policy explicitly focuses on both maintaining agricultural production in the mountain regions by promoting more competitive structures and the support of mountain ecosystem goods and services (Lanz, 2012).

The remainder of this paper is structured as follows. In the next section, we introduce the policy background of structural change in Swiss mountain agriculture and also present an overview of factors determining farm growth strategies identified in the literature. Then we describe the case study regions, the data collection and the empirical analyses conducted. After presenting the results, the final section proposes a discussion and conclusions.

\section{Background}

\section{Policy context}

Agricultural production in Swiss mountain regions is facing four particular economic and political boundary conditions that influence farm structural change. Firstly, farms in Switzerland benefit from one of the highest levels of government support worldwide (OECD, 2014). More specifically, over half their income is generated by government support schemes, i.e., either border protection or direct payments (Huber and Lehmann, 2010). In addition, Switzerland's subsidy system is based on decoupled payments which in general lowers the probability of farm disinvestment (Kazukauskas et al., 2013) and encourages small farms to extensify their production rather than to exit the sector (Mann, 2005). Secondly, compared to other mountain regions with increasing depopulation, off-farm employment is accessible thanks to the good performance of the overall economy in Switzerland (Baltensweiler and Erdin, 2005). Thus, farms are confronted with high opportunity costs, i.e., the measure of benefits forgone due to alternative uses of labor. This is particularly true in Central Switzerland where mountain regions and urban centers lie close together (Matti and Stotten, 2011) and off-farm opportunities in tourism exist. Thirdly, rural identity i.e., the values that farmers associate with the agricultural landscape and their work, still forms a strong background for the survival of farms, especially in mountain regions (Lauber, 2006). Farmers state that they have a strong bond with their work and their environment (FOAG, 2013) and the prospect of part-time farming does not deter young farmers from entering the sector (Mann, 2007, Rossier and Wyss, 2007). Fourthly, investment capital is abundant in Switzerland. Due to high off-farm wages, low interest rates and government support, farms can reinvest in new technologies and farm buildings resulting in a capital intensive agriculture (Baur, 1999).

Due to these factors, farm structural change in Swiss mountain regions is so far characterized by a relatively slow decline in the number of farms and the area of land cultivated has not declined as fast as in other European mountain regions in recent years (Flury et al., 2013, Streifeneder et al., 2007). The first development is contrary to the goals of Swiss agricultural policy, which aims to increase the 
competitiveness of Swiss family farms by means of various measures supporting farm growth in the farm succession phase (FOAG, 2009, Huber et al., 2014). This policy goal seeks to intensify structural change e.g. by increasing the number of small farm exits when the owner of the farm retires. It aims to increase the availability of land for larger and specialized farms with plans to grow and exploit economies of scale. The underlying policy mechanism is to restrict certain support measures to farms of a given size. In these policy measures, the assessment of farm size is based on standard labor units (SLU)1. This measure is applied in three major policy schemes supporting farm growth in the context of family farm succession (Hofer, 2008). Firstly, farms with more than one SLU can benefit from a low farm acquisition price if a successor is taking over the family business (family succession). This lowers the burden of debt financing and thus the cost of debt. Secondly, farms with at least one SLU can apply for loans and funding contributions to invest in farm buildings. This supports economies of scale and thus the competitiveness of the farms. Thirdly, farms of a size higher than one SLU can benefit from an entrance premium for the young farmer who takes over the business. In general, these instruments reduce farm debt and increase the probability of the farm's long-term survival. Farms below the size of one SLU cannot benefit from these schemes and thus the likelihood that they will exit the sector increases. Recent assessments show that farm size and the development of SLU are highly correlated (Huber et al., 2014). Changes in SLU, especially in mountain regions, are directly linked to changes in farm size. These points underline that under current agricultural policy conditions in Switzerland, an SLU of 1 can be viewed as a critical threshold, which will be considered in subsequent steps of our analysis.

Given the observed relatively small farm structural change, the effectiveness of these policies comes under question. The exclusive focus on farm size does not take into account the diversity of drivers, including farm family characteristics that influence farm structural change. These factors, in turn, may manifest themselves in stated farm development strategies (Bartolini and Viaggi, 2013, Latruffe et al., 2013). Thus, the analysis of intended farm development strategies is one possibility to assess the role of less tangible (social) factors in farm structural change. This is the starting point for our analysis, which aims to identify factors that determine stated growth intentions of mountain farms in Central Switzerland.

\section{Drivers of structural change}

Existing literature on ex-post analysis of structural change rooted in economic theory suggests multiple factors that influence the allocation of production factors, in particular the allocation of labor (reviews in Buchenrieder et al., 2007, Mann, 2003b, Zimmermann et al., 2009). In general, there are multiple drivers behind these processes including economic growth as a whole, adoption of new technology, off-farm employment, human (managerial) capital, market structure, investment constraints, social networks, as well as the existing policy environment (Akimowicz et al., 2013, Breustedt and Glauben, 2007, Chavas, 2001, Huettel and Margarian, 2009, Margarian, 2007, Storm et al., 2014, Weiss, 1999, Zimmermann and Heckelei, 2012).

In addition to these economic centered drivers, literature on rural sociology emphasizes the importance of socio-cultural factors to explain the persistence of family farms in Western European countries (Evans, 2009, Lobley and Potter, 2004, Rossier et al., 2012). In this context, farm restructuring is discussed in a multitude of concepts such as development pathways (e.g. Meert et al., 2005), elements of individual farm adjustments (e.g. Evans, 2009), rural development dynamics (Marsden et al., 2002) or transition theory (Darnhofer et al., 2015, Wilson, 2007). Two aspects from this literature are important in the context of assessing farm growth intentions. Firstly, even though family farms persist, they may significantly change household and production patterns through diversification i.e., restructuring of labor and an increase in capital from outside agriculture (Lobley and Potter, 2004). In this context, Wilson (2009) considers farm structural change as a spatially heterogeneous and highly dynamic process along a productivist/non-productivist multifunctionality spectrum. Secondly, farm types 
such as agri-businesses, part-time or upland farms exhibit different transitional pathways within a certain decision-making corridor which reflects economic, environmental as well as social and individual characteristics (Wilson, 2008). In this concept, transitions may be characterized by relative linear transitional patterns for certain periods of time interrupted by sudden changes (nodal changes) often seen during succession processes.

Based on this background, we consider farm characteristics (i.e., economic factors) and farmers' and family characteristics (i.e., socio-cultural factors) as independent variables to explain stated growth intentions. The dependent variable is defined by a stated intention to increase farm size (in ha) or to increase family labor input for on-farm diversification. Variables in our study have been selected following the literature in the field (Akimowicz et al., 2013, Breustedt and Glauben, 2007, Chavas, 2001, Weiss, 1999, Zimmermann and Heckelei, 2012), as well as publications that have addressed the case of Switzerland in particular (Baltensweiler and Erdin, 2005, Baur, 1999, Mann, 2003a, Mann, 2003b). These variables had also been used in different combinations to assess stated intentions with respect to farm exits (Latruffe et al., 2013, Raggi et al., 2013), farm size change (Bartolini and Viaggi, 2013), structural change (Barnes et al., 2014, Lobley and Butler, 2010, O'Donnell et al., 2011) and fallow land (Bougherara and Latruffe, 2010). The particular variables chosen, as well as the hypotheses associated with those variables that are usually considered in the literature, are presented in the subsequent sections and in Table 1.

\section{Farm characteristics}

We hypothesize that initial farm size (measured in ha) and the eligibility for political farm support (measured in SLU) increase intentions to grow based on theoretical considerations (Mann, 2003b), empirical findings (Storm et al., 2014, Weiss, 1999) and studies assessing farm strategies (Latruffe et al., 2013). Since farms are relatively small, we do not expect that larger farms will reveal a higher probability to state that they intend to reduce their land as suggested by other authors (Bartolini and Viaggi, 2013, Raggi et al., 2013). In this context, Mann (2005) shows that in Switzerland, farm size increase is even associated with land-use intensification. Farms with production overcapacities are likely to state farm growth intentions since they wish to recover sunk costs. We use the stated capacities to cultivate more land or to house more animals with existing production resources as a proxy to reflect sunk costs on the farms. Based on the literature, we expect that farm growth intentions will increase with higher sunk costs (Lauber, 2006, Zimmermann and Heckelei, 2012). In addition, we expect farms which grew in the past years to exhibit a higher probability to state farm growth intentions in the future since past behavior is assumed also to influence current strategies (Barnes et al., 2014, O'Donnell et al., 2011). This also implies that a reduced farm size is expected to be an indicator for a general trend of decline that is likely to be continued in the future. Furthermore, we assume that farm diversification will also increase farm growth intentions. The results from the literature vary on the subject of agricultural diversification and farm structural change (Latruffe et al., 2013, Mann, 2003b, Maye et al., 2009). However, since we also defined farm growth as an increase in family labor on the farm, we expect that farm diversification in the past i.e., the diversification of activities that are run on the farm or are dependent on farm-based land and capital assets (Maye et al., 2009), will increase farm growth intentions. With respect to off-farm employment, we hypothesize that the presence of household income from outside the farm will have no effect on the probability of farm exit or land decrease (Latruffe et al., 2013), but it is assumed to reduce the intention to grow (Lobley and Butler, 2010). In addition, we also included farm type and production method (organic or not) to control for specific farm production diversity and the canton (as dummy variable) to reflect natural and structural differences (e.g. Bartolini and Viaggi, 2013, Latruffe et al., 2013, Raggi et al., 2013). Stated growth intentions are expected to be less likely for more difficult production conditions, expressed by a higher score of the zone variable and organic dairy farms (Breustedt and Mees, 2010). 
Table 1. Definition of variables and source of data.

\begin{tabular}{|c|c|c|c|}
\hline Category & Variable & Description & Source \\
\hline & Dependent variable & & \\
\hline & Stated growth preference & 1: Farm stated growth intention; 0: farm did not state growth intention & Survey \\
\hline & Explanatory variables & & \\
\hline \multirow{10}{*}{ Farm characteristics } & Canton & Canton to which the farms belong (0 Uri/1 NW) & \multirow{6}{*}{ Census } \\
\hline & Zone & $\begin{array}{l}\text { Administrative zone according to the Federal Office (FOAG, 2014) 1: valley bottom and hillside; } 2 \text { : mountain re- } \\
\text { gions I-II, 3: mountain regions III-IV }\end{array}$ & \\
\hline & Farm size & Farm size in hectares & \\
\hline & Relative changes in size & Changes in farmland size between 2003 and 2011 & \\
\hline & SLU category & Administrative standardized farm size based on labor units (standardized labor units SLU) $0<=1 ; 1$ if $>1$ & \\
\hline & Organic & Organic farm yes (1) or no (0) & \\
\hline & Para & Farm diversification activities such as processing primary outputs, agro-tourism, direct sales, etc., 0: no/1 yes & \multirow{9}{*}{ Survey } \\
\hline & Off-farm employment & Off-farm employment of farmer (farm manager) yes (1) or no (0) & \\
\hline & Capacity & $\begin{array}{l}\text { Question in survey: how much more capacity do you have to cultivate more hectares with the current work force, } \\
\text { mechanization and housing capacities (proxy for sunk costs) } 1: 0 \% ; 2: 0-20 \% ; 3: 20-50 \% ; 4:>50\end{array}$ & \\
\hline & Age & Age of farmer in years (linear and squared) & \\
\hline \multirow{5}{*}{$\begin{array}{l}\text { Farmers' and Family } \\
\text { characteristics }\end{array}$} & Succession & $\begin{array}{l}\text { Farmer is younger than } 45 \text { years or there is a designated successor [1], farmer is between } 45 \text { and } 55 \text { and succes- } \\
\text { sion is unclear [2], farmer is over } 55 \text { years old and there is no successor [3] }\end{array}$ & \\
\hline & Education & No agricultural education or basic apprenticeship [1], agricultural training [2], higher agricultural training [3] & \\
\hline & Workload & $\begin{array}{l}\text { Perceived workload. Question in survey: workload on my farm is too high... 1: fully agree; 2: agree; 3: sometimes; } \\
\text { 4: do not agree; 5: completely disagree }\end{array}$ & \\
\hline & Stress & $\begin{array}{l}\text { Perceived psychological stress. Question in survey: psychological stress is high... 1: fully agree; 2: agree; } 3 \text { : some- } \\
\text { times; 4: do not agree; 5: completely disagree }\end{array}$ & \\
\hline & Finance & $\begin{array}{l}\text { Perceived financial problems. Question in survey: our financial problems are a burden... 1: fully agree; } 2: \text { agree; } 3 \text { : } \\
\text { sometimes; 4: do not agree; 5: completely disagree }\end{array}$ & \\
\hline
\end{tabular}




\section{Farmers' and family characteristics}

We included different individual variables such as age, succession, education and the perceived situation with respect to workload, psychological stress and financial problems in our analysis. We refer to this set of variables as family characteristics. We hypothesize that younger farmers or a defined succession status will increase farm growth intentions (Baltensweiler and Erdin, 2005, Baur, 1999, Mann, 2003a). Furthermore, to account for the hypothesis of a u-shaped form of farm investment (Mann et al., 2013), we consider a u-shaped relationship between age and farm investments. The expected effects of age and observed changes in farm size in the past must also be framed in the context of the farm life cycle concept (Calus et al., 2008, Weiss, 1999). Thus, depending, among other things, on the age of the farmer, the farm is expected to be in a growth, maturity or decline phase. In particular, younger farmers are expected to grow, while older farmers are expected to be rather in maturity or decline phases. However, we expect to observe a different picture for farms with higher certainty of succession. Farms with a successor do not enter the decline phase in the farm life cycle, but rather tend to boost the growth process (Calus and Van Huylenbroeck, 2008, Calus et al., 2008, Rossier et al., 2012). In the literature, farm growth and farm growth intention is also associated with higher education levels (Baur, 1999, Latruffe et al., 2013). Higher education levels are hypothesized to increase farm growth intentions (e.g. Bartolini and Viaggi, 2013, Baur, 1999). Furthermore, we expect that farmers who perceive their actual situation as labor-intensive or associate their work with psychological stress will exhibit less intentions to grow. This hypothesis is derived from workshops with farmers in the case study regions. In these workshops farmers' representatives stated that the main challenge for farms growth would be the restricted labor availability due to missing economies of scale in mountain regions (Flury, 2012, Huber and Flury, 2014). The same would also be expected in case of financial problems as growth is less likely in the event of financial restrictions.

\section{Method}

\section{Case study regions}

The cantons of Uri and Nidwalden (location of capitals $46^{\circ} 45^{\prime} 0^{\prime \prime} \mathrm{N}, 8^{\circ} 39^{\prime} 0^{\prime \prime} \mathrm{E}$ and $46^{\circ} 57^{\prime} 0^{\prime \prime} \mathrm{N}, 8^{\circ} 24^{\prime} 0^{\prime \prime} \mathrm{E}$, respectively) are situated in Central Switzerland. Both cantons are in the middle of mountain chains. Characteristics of the agricultural sector in the cantons are presented in Table 2 (for details see Flury, 2012, Huber and Flury, 2014). Even though the canton Uri is much larger than Nidwalden and has more farms, the agricultural area cultivated in both cantons is comparable in size since a large part of Uri consists of unproductive land (56\%), summer pastures (18\%) and forest (18\%). In Nidwalden, the amount of unproductive land, summer pastures and forests accounts for $24 \%, 18 \%$ and $33 \%$ respectively. While a large part of the agricultural area in Uri is located at high altitudes with a short vegetation period, most of the cultivated area in Nidwalden is located at medium altitudes between the lowest valley (432 m.a.s.l.) and the highest mountains (2901 m.a.s.l.). Due to climatic, topographic and basic structural conditions as well as the policy and market environment, average farm sizes in the two cantons are rather small with 10.7 and 12.3 ha in Uri and Nidwalden respectively. Uri has a higher share of farms smaller than $1 \mathrm{SLU}$ and the share of part-time farms in Uri (42\%) is also higher than in Nidwalden (30\%). The average share of part-time farmers in Swiss mountain regions is $33 \%$. Thus, in line with other mountain regions (López-i-Gelats et al., 2011, Pinter and Kirner, 2014), farm diversification played a considerable role in farm development in recent years (Flury, 2012, Huber and Flury, 2014). Approximately one third of the farms has allocated family labor to diversification such as tourism, food processing or forest services. The natural production conditions in the two cantons favor grassland production systems. Thus, most of these farms are devoted to livestock. Over $70 \%$ of the farmers keep dairy cows, mostly combined with calves and cattle breeding. 14 and $21 \%$ of the farms keep suckler cows in Uri and Nidwalden respectively. To lesser extent, small ruminants (sheep and goats) are also kept on the farms. Seasonal alpine grazing i.e., migration of livestock between alpine pastures in the summer season and lower altitudes the rest of the year, plays an important role for agriculture in these 
areas since the additional fodder-crop area enables farms to increase their livestock numbers (Mack et al., 2013).

Table 2. Characteristics of case study regions.

\begin{tabular}{|c|c|c|}
\hline & Uri & Nidwalden \\
\hline Inhabitants per km² 2011 & 32.9 & 149.6 \\
\hline Area $2004 / 09^{\text {a }}\left(\mathrm{km}^{2}\right)$ & 1076 & 276 \\
\hline Settlement and infrastructure (\%) & 1 & 5 \\
\hline Agricultural area (\%) & 7 & 19 \\
\hline Summer pastures (\%) & 18 & 18 \\
\hline Forest $(\%)$ & 18 & 33 \\
\hline Unproductive land (\%) & 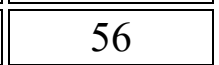 & 25 \\
\hline Total agricultural area (ha) $2011^{\underline{b}}$ & 6777 & 6057 \\
\hline Valley and hillside & $699(10 \%)$ & $1215(20 \%)$ \\
\hline Mountain zone I-II & $1480(22 \%)$ & $3893(64 \%)$ \\
\hline Mountain zone III-IV & $4598(68 \%)$ & $949(16 \%)$ \\
\hline Summer pastures 2004/09 (ha) & 20,787 & 4939 \\
\hline Number of farms 2011 & 633 & 493 \\
\hline Number of livestock (livestock units ${ }^{\mathrm{c}}$ ) & 8600 & 10,850 \\
\hline Cattle (\%) & 82 & 76 \\
\hline Pigs (\%) & 5 & 15 \\
\hline Small ruminants (\%) & 9 & 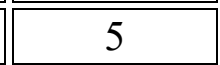 \\
\hline Average farm size (ha) in 2011 & 10.7 & 12.3 \\
\hline Share of farms with less than 1 SLU 2011 & 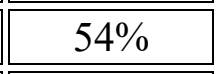 & $35 \%$ \\
\hline Share of part-time farming (\%) & $42 \%$ & $30 \%$ \\
\hline Share of farm with diversification (\%) & 32 & 37 \\
\hline Mean annual structural change 2003-10/11 (\%) & $-1.9 \%$ & $-1.3 \%$ \\
\hline Mean annual growth in cultivated land per farm 2003-2010/11 (ha) & $+2.0 \%$ & $+1.1 \%$ \\
\hline Mean annual investment credits per farm 2003-2010/11 (CHF) & 20,130 & $\begin{array}{l}38,310 \\
\end{array}$ \\
\hline Mean annual direct payments (CHF) & 40,000 & 40,000 \\
\hline
\end{tabular}

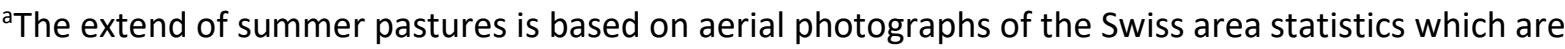
periodically inventorized (FSO, 2014).

${ }^{\mathrm{b}}$ To target policy measures, the total agricultural area in Switzerland is divided into administrative zones based on climatic and topographical differences as well as differences in local public infrastructure (for an online map see FOAG, 2014). From the valley region to the mountain zone IV, agricultural production potential gradually decreases.

CLivestock units (LU): conversion factor from number to LU: cow 1; breeding cattle 0.6 ; calf 0.3 ; pig 0.4 (average) sheep and goat 0.2 (average).

Source: Huber and Flury (2014), Flury (2012).

In the period 2003-2011, only a small decline of the number of farms was observed. The annual decline in the number of farms between 2003 and 2011 was greater in Uri (-1.9\%) than in Nidwalden $(-1.3 \%)$, while the Swiss average was $-1.6 \%$. Consequently, average farm growth was also higher in Uri. The 
cantons also differ with respect to policy measures supporting farm growth, as Nidwalden accounts for higher investment credits per year and farm than Uri. Additionally, the farms in these two cantons profit from direct payments of about CHF 25 million, and CHF 20 million, in Uri and Nidwalden respectively. Thus, farms are on average supported by $\mathrm{CHF} 40,000$ per year which is higher than average farm income in Swiss mountain regions.

\section{Data collection}

A survey of farmers in two cantons of Central Switzerland was carried out to analyze the influence of a set of factors on the farmers' stated intentions to increase farm size in terms of utilized farmland or increased family labor input within the next 10 years (Questionnaire in Appendix A). The surveys were attached to the official application form for direct payments in 2010 in Uri and 2011 in Nidwalden. This led to a high response rate of 412 (65\%) and 251 (51\%) farms in Uri and Nidwalden respectively (total $\mathrm{n}=663$ ) with a good representativeness of existing farms. Only farms with less than five hectares of agricultural surface were underrepresented in the sample (Flury, 2012, Huber and Flury, 2014). Hobby farms are excluded from direct payments in Switzerland and thus were not surveyed. In addition, we used the official census data on farm activities (e.g. farmed land, land-use, number of animals and other farm characteristics) in the data base of the Federal Office for Agriculture. Since these data are based on the direct payment application, the farm activities for a timespan of seven and eight years in Uri and Nidwalden respectively could be linked to the survey data via the ID number in the application form.

\section{Empirical analysis}

In a first step, we compare farms that stated the intention to grow and those who did not, based on the variables presented in Table 1 using Mann-Whitney tests to assess the significance of differences between the two groups. Although farm structural change is also associated with aspects of outsourcing of work (farm labor contractor) and part-time farming (Mann, 2003b), we focus here on aspects of farm growth in general i.e., an increase in farmland cultivated or an increase in labor of the farm manager on the farm with regard to farm specialization or diversification (Lange et al., 2013). Next, we use a logistic regression to determine the most decisive variables associated with a growth strategy choice.

$\mathrm{Gi}$ is the binary information (Yes/No) on the stated growth intention for $i=1, \ldots, n$ farms. $\pi i$ is the expectation that $\mathrm{Gi}=1$ given the set of farm specific explanatory variables $\mathrm{Xi}$. In binary logistic regression this response probability is modeled as follows:

Given a certain set of $X$, the odds of response $G=1$ is equal to $\pi /(1-\pi)$, and is also the vector of model intercept, the vector of regression coefficients including an intercept and the vector of error terms. We present the exponential of coefficient estimates to illustrate the multiplicative change in the odds (for $\mathrm{G}=1$ ), when the ith variable increases by one unit and all other variables remain constant:

Cross-validation is conducted using a randomly selected training and validation dataset each containing $50 \%$ of the observations. The regression is performed using the training dataset while coefficient estimates serve to predict stated growth intentions for the observations in the validation dataset. This cross validation procedure is repeated 1000 times for each model. Average percentages of correct predictions are presented. 
Variables were selected using a stepwise selection procedure that combines both forward selection and backward elimination based on the Akaike criterion. We tested for remaining potential problems of multicollinearity by estimating the variance inflation factors of the selected model (Fox and Monette, 1992). Sensitivity analyses are conducted with reduced models to confirm the stability of the derived results. Furthermore, to test for the effect of farm diversification activities (Variable Para, see Table 1) that is especially relevant for our case study (Mann, 2003b), at least one model is estimated that accounts for this factor. All analyses are conducted using the R statistical language and environment (R Development Core Team, 2010).

\section{Results}

Results are presented with respect to the group comparison between farms with and without intentions to grow (Table 3 presenting mean values) and two regression models (Table 4).

Table 3. Comparison of factors explaining farm growth intentions (sample means).

\begin{tabular}{|l|c|c|}
\hline \multicolumn{1}{|c|}{ Variables } & $\begin{array}{c}\text { No growth inten- } \\
\text { tion }\end{array}$ & Growth intention \\
\hline \hline Canton (0-Uri, 1-NW) & $0.33^{*}$ & 0.40 \\
\hline \hline Farm size (in ha) & $10.90^{* * *}$ & 13.31 \\
\hline Relative changes in farm size (2003-2011) & $-0.07^{* * *}$ & 0.06 \\
\hline \hline SLU category & $0.47^{* * *}$ & 0.69 \\
\hline Zone (1-, 2-, 3-) & $2.64^{*}$ & 2.53 \\
\hline \hline Organic [0,1] & $0.11(\mathrm{~ns})$ & 0.15 \\
\hline Succession [1-3] & $1.87^{* * *}$ & 1.40 \\
\hline Para & $0.05^{* * *}$ & 0.13 \\
\hline \hline Workload & $2.45(\mathrm{~ns})$ & 2.45 \\
\hline \hline Psychological stress & $3.11^{*}$ & 2.97 \\
\hline Financial problems & $2.95(\mathrm{~ns})$ & 2.97 \\
\hline \hline Age (in years) & $54.58^{* * *}$ & 47.21 \\
\hline \hline Capacity labor & $1.73^{* * *}$ & 2.49 \\
\hline \hline Capacity mechanization & $2.01^{* * *}$ & 2.82 \\
\hline \hline Capacity housing & $1.79^{* * * *}$ & 2.35 \\
\hline \hline Education [1-3] & $1.42(\mathrm{~ns})$ & 1.76 \\
\hline \hline Off-farm employment & $0.55(\mathrm{~ns})$ & 0.49 \\
\hline \hline Number of observations & 209 & 454 \\
\hline
\end{tabular}

ns (not significant) indicates that the null hypothesis of no differences between groups could not be rejected at the $10 \%$ level.

*Significance at the $10 \%$ level of the Mann-Whitney test.

***Significance at the $1 \%$ level of the Mann-Whitney test. 
Table 4. Results from the logistic regression models.

\begin{tabular}{|l|c|c|}
\hline \multicolumn{1}{|c|}{ Variable } & Model 1 & Model 2 \\
\hline \hline Intercept & $8.18(2.79)^{* * *}$ & $7.71(2.69)^{* * *}$ \\
\hline \hline Age & $0.95(-3.80)^{* * *}$ & $0.95(-3.80)^{* * *}$ \\
\hline \hline Relative change in farm size & $5.52(3.66)^{* * *}$ & $5.42(3.62)^{* * *}$ \\
\hline \hline SLU category & $1.62(2.12)^{* *}$ & $1.59(2.01)^{* * *}$ \\
\hline \hline Succession & $0.76(-1.76)^{*}$ & $0.76(-1.70)^{*}$ \\
\hline \hline Overcapacity in mechanization & $1.86(5.66)^{* * *}$ & $1.87(5.69)^{* * *}$ \\
\hline \hline Para & - & $2.33(1.99)^{* * *}$ \\
\hline \hline Number of observations & 545 & 545 \\
\hline \hline Correct predictions & & $77 \%$ \\
\hline
\end{tabular}

Numbers in parentheses are z-values.

* Significance at the $10 \%$ level.

$* *$ Significance at the $5 \%$ level.

***Significance at the $1 \%$ level.

Number of observations used in the logistic regression is decreased due to missing values.

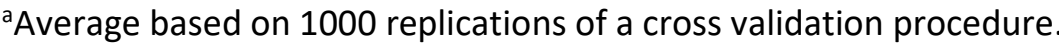

$68 \%$ of the farmers state an intention to grow in the near future. The main farm characteristics that significantly differentiate farms which state their intention to grow from those that do not are: farm size, relative changes in farm size, SLU category, farm has diversified/not diversified its production and the capacity variables which can be interpreted as sunk costs. The findings presented in Table 3 confirm the hypotheses formulated in Section 'Background'. More specifically, our results show:

(i) Farm size: On average, the size of farms which intend to grow is two hectares bigger than those with no intention to grow.

(ii) Relative changes in farm size: Farms that intend to grow increased their size (measured in hectares) during the last years. In contrast, farms that have no intentions to grow tend to have reduced their size in the past.

(iii) SLU category: Farms which intend to grow are also bigger with respect to the SLU, i.e., the administrative size used by the authorities.

(iv) (iv) Para: The two groups can also be differentiated according to whether or not they have diversified their farm activities. Farms which diversified are more likely to state farm growth intentions.

(v) Capacity: Farms that intend to grow have higher capacity to cultivate more agricultural land with existing fixed input factors. If this is used as an approximation of sunk costs, those farms which intent to grow have higher sunk costs. In addition, the age of the farmers and the succession status are two further variables which differ between the two groups of farmers and which also confirm our hypotheses.

(vi) Age: Farmers who intent to grow are younger than those who do not state this intention.

(vii) Succession: Farms with a higher uncertainty about succession state lower growth intentions.

Although less significant, geographical variables also differ between the two groups. The share of farmers who intend to grow is greater in Nidwalden than in Uri and farmers in higher regions tend to declare less growth intentions. This reflects the natural and structural differences between and within the cantons, also with respect to the other variables considered in our analysis (cf. Table 1). In addition, per- 
ceived stress is lower on those farms which intent to grow. However, we did - in contrast to our expectations - not find any significant difference between the two groups with respect to perceived workload or financial problems (Table 3). Furthermore, we could not find any of the expected differences concerning off-farm employment, education and farm type (organic production). The latter finding is probably due to the small share of organic farming in both cantons.

Next, we present results for the logistic regression analysis (Table 4). Using the stepwise selection procedure based on the Akaike criterion, the factors age, changes in farm size, SLU category, succession and overcapacities in mechanization are suggested for inclusion in the model (Model 1 in Table 4) and thus represent the most decisive variables associated with a growth strategy choice. Note that correlation between variables (not shown) reveals that the variable "overcapacities in mechanization" often represents general overcapacities (i.e., also with respect to labor and housing) and thus sunk costs. The consideration of age in both linear and squared form was rejected in favor of the model containing age in linear terms only, as presented below. Due to the specific potential relevance of farm diversification (Variable Para), we also tested this factor for inclusion in the regression model and estimated a separate regression model (Model 2 in Table 4).

The coefficients provided by the logistic regression models are odds ratios representing the multiplicative change in the odds for a farm to state growth intentions when the ith variable increases by one unit and all other variables remain constant. Thus, a positive (negative) influence of the respective variable on the adoption probability is indicated if coefficient estimates are larger (smaller) than one. All signs of coefficient estimates are as expected (compare Table 1)2. More specifically, the results from the regression analysis suggest that the odds to state farm growth intentions decrease with the farmer's age and with a decreasing certainty regarding farm succession (i.e., a higher value of the Variable Para). Moreover, a relative increase in farm size over the last 8 years, higher overcapacities and higher SLU values increase the odds that farmers state growth intentions. The inclusion of Para in the model indicates that diversification has a positive effect on farm growth intentions. Furthermore, this inclusion affects neither the magnitude nor the significance of estimated effects as tested in a sensitivity analysis (see Appendix B).

\section{Discussion and conclusions}

Our analysis of factors influencing farm growth intentions in two mountain regions in Switzerland has three major implications for the assessment of future structural change and the effectiveness of public policies to support farm growth.

Firstly, the economic factors which support farm growth intentions in our case study regions appear to tally with studies from other European regions and with the factors driving observed patterns. Based on the coefficients of our regression models, we conclude that farm growth intentions are influenced primarily by structural characteristics such as relative farm size change in the past, current farm size and sunk costs proxied in our survey with stated overcapacities. This corresponds with our expectations since these factors are also decisive when analyzing observed farm structural change in general (Akimowicz et al., 2013, Breustedt and Glauben, 2007, Weiss, 1999) and also correspond with recent studies that assess future intentions of farmers under different policy settings and scenarios (e.g. Bartolini and Viaggi, 2013, Bougherara and Latruffe, 2010, Latruffe et al., 2013, Lobley and Butler, 2010, O'Donnell et al., 2011, Raggi et al., 2013). Furthermore and in line with our hypothesis, younger farmers are more likely to state growth intentions. This confirms farm life cycle effects also identified in other European Regions (Latruffe et al., 2013, Raggi et al., 2013) and is also consistent with empirical research in Switzerland (Baltensweiler and Erdin, 2005, Baur, 1999, Mann, 2003a). Although recent research suggests the existence of a u-shaped form of farm investments behavior (Mann et al., 2013), we could not find such an effect on farm growth intentions in our analysis. 
Secondly, the limited availability of labor within a family may result in a new critical threshold for farm growth strategies in mountain regions. This conclusion is based on our finding that perceived workload and financial problems did not influence farm growth strategies, i.e., no difference between farmers who stated growth intentions vs. farmers who did not. Farmers in our survey tend to agree with the statement that the workload on their farm is too high but they still state the intention to grow. In this respect, Lobley and Butler (2010) also show in their results that so called expanders, i.e., farmers who intent to increase their farm's scale, agreed less on the statement that they are satisfied with the amount of leisure time they have compared to other farm type clusters. Evidently, many farmers understand growth as an essential strategy to stay in the sector - regardless of their workload and financial problems. The latter may be justified because farm size growth is associated with economic efficiency and is thus desirable from an economic point of view. However, long-term disregard for the factor of workload may result in a reduction of quality of life, i.e., acceptable working conditions, including the farmers' expectations with respect to farming, family life and other activities (Milestad et al., 2012). Thus, the perceived workload may act as an important driver of nodal changes (Wilson, 2008) i.e., disruptive changes in the succession of family farms in Swiss mountain regions.

Thirdly, the results of our survey imply that farm growth intentions are not impeded by off-farm employment since we could not find a significant difference between the farm groups. This is in contrast to empirical findings on farm structural change (Akimowicz et al., 2013, Aldanondo Ochoa et al., 2007, López-i-Gelats et al., 2011, Weiss, 1999). On the one hand, this may be explained by the specific policy and economic environment in Switzerland which did not result in a dual structure of the farming sector (Baur, 1999). On the other hand, most of the farmers in our case study regions clearly reveal their aim to remain in the sector irrespectively of their opportunity costs and education level. Since farm diversification also has a positive impact on farm growth intentions in our analysis, the observed process of slow structural change and increased diversification is also reflected in the farmers' stated intentions; mirroring the fact that marginal farms adapt to new environments and try to cope with crisis (Lobley and Potter, 2004). To some extent, these findings are also contrary to the strategies in Austrian mountain regions where more farmers tend to disengage and where diversification is not seen as an option generating sufficient revenues (Pinter and Kirner, 2014). This divergence in results may be due to the fact that the support level in Switzerland is still significantly higher than in Austria. Moreover, recent research in the US shows that decoupled payments i.e., payments that are not tied to production decisions or prices, which were consolidated in the last policy reform in Switzerland, may increase the supply of on-farm work (Key and Roberts, 2009). In combination with the high level of overcapacities on the farms, a rapid structural change, i.e., a reduction in the number of farms and re-allocation of resources in the near future cannot be expected in our case study regions. This confirms a certain pathdependency observed in farm structural change in general (Baltensweiler and Erdin, 2005, Zimmermann and Heckelei, 2012) and also specifically in mountain regions (e.g. Lauber, 2006). This is also in line with the literature in rural sociology explaining the persistence of family farming (Evans, 2009, Lobley and Potter, 2004, Wilson, 2008).

This leads to a dilemma for the farmers themselves. Assuming that most of the farmers want to grow, the lack of land available on the market will mean that only a minority of them will be able to achieve this goal (potentially those with a higher education level). However, recent research by Storm et al. (2014) suggests that high direct payments to neighboring farms decreases a farm's survival probability. This still may result in a coordination problem with regard to farm exits while growth-oriented farms will face the problem of choice of strategy as described theoretically in Margarian (2010). Therefore, the impact of policies supporting farm growth, as described in the Section 'Background', seems to be limited in this situation as it is linked to farm capacities and countervailed by direct payment policies. Farm and family characteristics in our case study areas appear to reinforce existing trends (e.g. Lobley and Butler, 2010) and reflect the difference between economic optimization and farmers' intentions (Breen et al., 2005, Gorton et al., 2008). Further questions concerning non-pecuniary advantages of farming in our survey of Nidwalden, which showed a strong connectedness to rural identities (Huber and Flury, 2014) and the fact that almost none of the farmers intended to disinvest, support these 
arguments and imply enhanced robustness for slow structural change. While intentions may change under different scenarios (Bartolini and Viaggi, 2013, Bougherara and Latruffe, 2010, Latruffe et al., 2013, O'Donnell et al., 2011, Raggi et al., 2013), farm structural change in these mountain regions will continue to be characterized by a relatively slow decline in the number of farms and an increasing share of part-time farmers and farmers with diversification activities. These farms must maintain their flexibility and diversity if they are to meet the challenge of future transformations and pressures which may well also include surprises and unexpected developments (e.g. Darnhofer et al., 2010).

Two crucial points must be borne in mind, when interpreting the practical implications of our findings. Firstly there is considerable uncertainty with respect to the assessment of future structural change in general and the development of mountain regions under global change associated with heterogeneity, non-linear developments, trade-offs and feedbacks in particular (Huber et al., 2013). It is unclear to what extent farmers' neglect of social factors in their decision-making strategy will persist under changing conditions. Secondly, our results are based on stated preferences and only partly on observed behavior. Even under the assumption that stated and future observed behavior can, to some extent, be aligned (Bartolini and Viaggi, 2013, Gorton et al., 2008, Viira et al., 2014), farm structural change will continue and some of the farms that state growth intentions will not find a successor and leave the sector. Thus, the farmers' views can be interpreted as a normative rather than a positive perspective on future developments (Mandryk et al., 2012). However, the difference between most of the farmers' intentions (they expect to remain in the sector, to grow or diversify if necessary) and the policy measures (which imply a certain level of farm exits to support farm growth) may undermine the acceptance of the policy and reveals an additional dimension for policy-makers and the administration. Thus, to understand the (non-)effectiveness of farm growth policies in Switzerland, farmers' intentions should be taken into account and a further criteria, in addition to the SLU criterion, defining the restriction of support measures should be examined e.g. a farm based assessment of returns on investments. Furthermore, our study may indicate that family farms in mountain regions seem to neglect social factors in strategic decision-making, which - in the long run - may abruptly change the assessments of future structural change with and without policy changes.

\section{Acknowledgements}

We would like to thank all the farmers who took part in the survey (despite their high workload) and the administration of the cantons of Uri and Nidwalden for data provision and collaboration. We would also like to thank the two anonymous reviewers for their helpful comments on an earlier version of the manuscript. Many thanks to Jennifer Bays for English corrections. Parts of this work were supported by the Competence Center of Environment and Sustainability (CCES) of the ETH Domain.

\section{References}

Akimowicz, M.-B. Magrini, A. Ridier, J.-E. Bergez, D. Requier-Desjardins What influences farm size growth? An illustration in Southwestern France Appl. Econ. Perspect. Policy, 35 (2013), pp. 242-269

Aldanondo Ochoa, V. Casanovas Oliva, C. Almansa Sáez Explaining farm succession: the impact of farm location and off-farm employment opportunities Span. J. Agric. Res., 5 (2007), pp. 214-225

Baltensweiler, D. Erdin Ursachen des landwirtschaftlichen Strukturwandels Agrarforschung, 12 (2005), pp. 162-167

Barnes, L. Toma, K. Mathews, L.-A. Sutherland, S. Thomson Intensify, diversify, opt-out: testing farmer stated intentions to past and future CAP reform scenarios 88th Annual Conference of the Agricultural Economics Society, AgroParisTech, Paris, France (2014)

Bartoli, M. De Rosa Family farm business and access to rural development polices: a demographic perspective Agric. Food Econ., 1 (2013), p. 12 
Bartolini, V. Gallerani, M. Raggi, D. Viaggi Modelling the linkages between cross-compliance and agrienvironmental schemes under asymmetric information J. Agric. Econ., 63 (2012), pp. 310-330

Bartolini, D. Viaggi The common agricultural policy and the determinants of changes in EU farm size Land Use Policy, 31 (2013), pp. 126-135

Bau rAgrarstrukturwandel in der Schweiz Institut für Agrarwirtschaft, ETH Zurich (1999)

Bougherara, L. Latruffe Potential impact of the EU 2003 CAP reform on land idling decisions of French landowners: results from a survey of intentions Land Use Policy, 27 (2010), pp. 1153-1159

Breen, T.C. Hennessy, F.S. Thorne The effect of decoupling on the decision to produce: an Irish case study Food Policy, 30 (2005), pp. 129-144

Breustedt, T. Glauben Driving forces behind exiting from farming in Western Europe J. Agric. Econ., 58 (2007), pp. 115-127

Breustedt, M. Mees Growth of German dairy farms under the EU milk quota 114th Seminar of the European Association of Agricultural Economists, Berlin, Germany (2010)

Buchenrieder, J. Möllers, K. Happe, S. Davidova, L. Frederiksson, A. Bailey, M. Gorton, D.A. Kancs, J. Swinnen, L. Vranken, C. Hubbard, N. Ward, L. Janvancic, D. Milczarek, P. Mishev Conceptual Framework for Analysing Structural Change in Agriculture and Rural Livelihoods, Discussion Paper Leibniz Institute of Agricultural Development in Central and Eastern Europe (IAMO), Halle (Saale), Germany (2007)

Calus, G. Van Huylenbroeck The succession effect within management decisions of family farms 12th Congress of the European Association of Agricultural Economists - EAAE (2008)

Calus, G. Van Huylenbroeck, D. Van Lierde The relationship between farm succession and farm assets on Belgian farms Sociol. Rural., 48 (2008), pp. 38-56

Celio, C.G. Flint, P. Schoch, A. Grêt-Regamey Farmers' perception of their decision-making in relation to policy schemes: a comparison of case studies from Switzerland and the United States Land Use Policy, 41 (2014), pp. 163-171

Chavas Structural change in agricultural production: economics technology and policy Bruce, C.R. Gordon (Eds.), Handbook of Agricultural Economics, Elsevier (2001), pp. 263-285

Darnhofer Socio-technical transitions in farming: key concepts L.-A. Sutherland, I. Darnhofer, G. Wilson, L. Zagata (Eds.), Transition Pathways Towards Sustainability in Agriculture. Case Studies from Europe, CABI, Wallingford (2015), pp. 17-31

Darnhofer, J. Fairweather, H. Moller Assessing a farm's sustainability: insights from resilience thinking Int. J. Agric. Sustain., 8 (2010), pp. 186-198

Darnhofer, L.-A. Sutherland, T. Pinto-Correia Conceptual insights derived from case studies on 'emerging transitions' in farming L.-A. Sutherland, I. Darnhofer, G. Wilson, L. Zagata (Eds.), Transition Pathways Towards Sustainability in Agriculture. Case Studies from Europe, CABI, Wallingford (2015), pp. 189-203

Evans Adjustment strategies revisited: agricultural change in the Welsh Marches J. Rural Stud., 25 (2009), pp. 217-230

Flury Überprüfung der Landwirtschaftspolitik im Kanton Uri. Entwicklungsstrategie für die Urner Landund Alpwirtschaft. Bericht der Urner Regierung Flury-Giuliani GmbH und Amt für Landwirtschaft Uri, Zürich (2012)

Flury, R. Huber, E. Tasser Future of mountain agriculture in the Alps S. Mann (Ed.), The Future of Mountain Agriculture, Springer, Berlin/Heidelberg (2013), pp. 105-126

FOAG Swiss Agriculture on the Move. The New Agriculture Act Ten Years on Swiss Federal Department of Economic Affairs FDEA and Federal Office for Agriculture FOAG Federal Office for Agriculture (FOAG) (2009), pp. 1-31 http://www.blw.admin.ch/aktuell/index.html?lang=en 
FOAG Agricultural Report 2013 Federal Office for Agriculture (FOAG), Bern (2013), pp. 1-16 Available at: http://www.blw.admin.ch/dokumentation/00018/00498/index.html?lang=en

FOAG Zonenkarte Federal Office for Agriculture (FOAG), Bern (2014) http://www.blw.admin.ch/themen/00015/00182/

Fox, G. Monette Generalized Collinearity Diagnostics J. Am. Stat. Assoc., 87 (1992), pp. 178-183

FSO Arealstatistik Swiss Federal Statistical Office (FSO), Neuchâtel (2014) http://www.bfs.admin.ch/bfs/portal/de/index/themen/02/03.html

Gorton, E. Douarin, S. Davidova, L. Latruffe Attitudes to agricultural policy and farming futures in the context of the 2003 CAP reform: a comparison of farmers in selected established and new Member States J. Rural Stud., 24 (2008), pp. 322-336

Grêt-Regamey, S.H. Brunner, F. Kienast Mountain ecosystems services: who cares? Mt. Res. Dev., 32 (2012), pp. 23-34

Hofer Erhöhung der Gewerbegrenze nach Artikel 7 BGBB: Auswirkungen Blätter für Agrarrecht, 42 (2008), pp. 235-256

Huber, C. Flury Analyse und Perspektiven der Landwirtschaft im Kanton Nidwalden. Bericht zuhanden des Forums Nidwalden Flury-Giuliani GmbH, Zürich (2014)

Huber, B. Lehmann WTO agreement on agriculture: potential consequences for agricultural production and land-use patterns in the Swiss lowlands Dan. J. Geogr., 109 (2010), pp. 131-145

Huber, B. Meier, C. Flury Evaluation, Weiterentwicklung und Alternativen des SAK-Systems, Bericht zuhanden des Bundesamts für Landwirtschaft Flury\&Giuliani $\mathrm{GmbH}$ /bemepro, Zürich/Winterthur (2014)

Huber, A. Rigling, P. Bebi, F.S. Brand, S. Briner, A. Buttler, C. Elkin, F. Gillet, A. Grêt-Regamey, C. Hirschi, H. Lischke, R.W. Scholz, R. Seidl, T. Spiegelberger, A. Walz, W. Zimmermann, H. Bugmann Sustainable land use in mountain regions under global change: synthesis across scales and disciplines Ecol. Soc. (2013), p. 18

Huettel, A. Margarian Structural change in the West German agricultural sector Agric. Econ., 40 (2009), pp. 759-772

Kazukauskas, C. Newman, D. Clancy, J. Sauer Disinvestment, farm size, and gradual farm exit: the impact of subsidy decoupling in a European context Am. J. Agric. Econ., 95 (2013), pp. 1068-1087

Key, M.J. Roberts Nonpecuniary benefits to farming: implications for supply response to decoupled payments Am. J. Agric. Econ., 91 (2009), pp. 1-18

Lange, A. Piorr, R. Siebert, I. Zasada Spatial differentiation of farm diversification: how rural attractiveness and vicinity to cities determine farm households' response to the CAP Land Use Policy, 31 (2013), pp. 136-144

Lanz Main Aspects of the Agricultural Policy for 2014-2017 Swiss Federal Department of Economic Affairs FDEA and Federal Office for Agriculture FOAG (2012) Accessed January 2013 (http://www.blw.admin.ch/aktuell/index.html?lang=en)

Latruffe, A. Dupuy, Y. Desjeux What would farmers' strategies be in a no-CAP situation? An illustration from two regions in France J. Rural Stud., 32 (2013), pp. 10-25

Lauber Agrarstrukturwandel im Berggebiet. ART Schriftenreihe (dissertation) ETH Nr. 16716, Zürich (2006), pp. 1-217

Lobley, A. Butler The impact of CAP reform on farmers' plans for the future: some evidence from South West England Food Policy, 35 (2010), pp. 341-348 
Lobley, C. Potter Agricultural change and restructuring: recent evidence from a survey of agricultural households in England J. Rural Stud., 20 (2004), pp. 499-510

López-i-Gelats, M.J. Milán, J. Bartolomé Is farming enough in mountain areas? Farm diversification in the Pyrenees Land Use Policy, 28 (2011), pp. 783-791

Mack, T. Walter, C. Flury Seasonal alpine grazing trends in Switzerland: economic importance and impact on biotic communities Environ. Sci. Policy, 32 (2013), pp. 48-57

Mandryk, P. Reidsma, M. Ittersum Scenarios of long-term farm structural change for application in climate change impact assessment Landsc. Ecol., 27 (2012), pp. 509-527

Mann Bestimmungsgründe des landwirtschaftlichen Strukturwandels Agrarforschung, 10 (2003), pp. 32-36

Mann Theory and practice of structural change in agriculture? Agrarwirtschaft, 52 (2003), pp. 140-148

Mann Farm size growth and participation in agri-environmental schemes: a configural frequency analysis of the Swiss case J. Agric. Econ., 56 (2005), pp. 373-384

Mann Tracing the process of becoming a farm successor on Swiss family farms Agric. Hum. Values, 24 (2007), pp. 435-443

Mann, S. Lanz Happy Tinbergen: Switzerland's new direct payment system EuroChoices, 12 (2013), pp. 24-28

Mann, K. Mittenzwei, F. Hasselmann The importance of succession on business growth: a case study of family farms in Switzerland and Norway Yearb. Socioecon. Agric., 2013 (2013), pp. 109-139

Margarian Mehr-Ebenen-Modelle in der Analyse agrarstruktureller Entwicklungen - Methodik und Implikationen Agrarwirtschaft, 56 (2007), pp. 340-353

Margarian Coordination and differentiation of strategies: the impact on farm growth of strategic interaction on the rental market for land GJAE, 59 (2010), pp. 202-216

Marsden, J. Banks, G. Bristow The social management of rural nature: understanding agrarian-based rural development Environ. Plan. A, 34 (2002), pp. 809-825

Matti, R. Stotten Demographic Change in Canton Nidwalden: Short Regional Report. Demochange: Output 4.5 - Work Package 4 (2011), pp. 150-159

Maye, B. Ilbery, D. Watts Farm diversification, tenancy and CAP reform: results from a survey of tenant farmers in England J. Rural Stud., 25 (2009), pp. 333-342

Meert, G. Van Huylenbroeck, T. Vernimmen, M. Bourgeois, E. van Hecke Farm household survival strategies and diversification on marginal farms J. Rural Stud., 21 (2005), pp. 81-97

Milestad, B. Dedieu, I. Darnhofer, S. Bellon Farms and farmers facing change: the adaptive approach I. Darnhofer, D. Gibbon, B. Dedieu (Eds.), Farming Systems Research into the 21st Century: The New Dynamic, Springer Science+Business Media, Dordrecht (2012), pp. 365-385

O'Donnell, B. Horan, A.M. Butler, L. Shalloo A survey of the factors affecting the future intentions of Irish dairy farmers J. Agric. Sci., 149 (2011), pp. 647-654

O'Brien A caution regarding rules of thumb for variance inflation factors Qual. Quant., 41 (2007), pp. 673-690

OECD Agricultural Policy Monitoring and Evaluation 2014 OECD Publishing (2014)

Pinter, L. Kirner Strategies of disadvantaged mountain dairy farmers as indicators of agricultural structural change: a case study of Murau, Austria Land Use Policy, 38 (2014), pp. 441-453

Raggi, L. Sardonini, D. Viaggi The effects of the Common Agricultural Policy on exit strategies and land re-allocation Land Use Policy, 31 (2013), pp. 114-125 
Renwick, T. Jansson, P.H. Verburg, C. Revoredo-Giha, W. Britz, A. Gocht, D. McCracken Policy reform and agricultural land abandonment in the EU Land Use Policy, 30 (2013), pp. 446-457

Rossier, I. Häberli, C. Jurt Wer übernimmt den elterlichen Hof? Schweizer Fallbeispiele im Zeitraum von zehn Jahren, 60, Zeitschrift fur Agrargeschichte und Agrarsoziologie (2012), p. 75

Rossier, B. Wyss Erwerbskombination - Kein Hindernis für die Hofnachfolge Agrarforschung, 14 (2007), pp. 108-113

Storm, K. Mittenzwei, T. Heckelei Direct payments, spatial competition, and farm survival in Norway Am. J. Agric. Econ. (2014), 10.1093/ajae/aau085 Advance Access published September 23, 2014

Streifeneder, U. Tappeiner, F. Ruffini, G. Tappeiner, C. Hoffmann Selected aspects of agro-structural change within the Alps J. Alp. Res., 95 (2007), pp. 41-52

R Development Core TeamR: A Language and Environment for Statistical Computing 3-900051-07-0, R Foundation for Statistical Computing, Vienna, Austria (2010) http://www.R-project.org

Tranter, A. Swinbank, M.J. Wooldridge, L. Costa, T. Knapp, G.P.J. Little, M.L. Sottomayor Implications for food production, land use and rural development of the European Union's Single Farm Payment: indications from a survey of farmers' intentions in Germany, Portugal and the UK Food Policy, 32 (2007), pp. 656-671

Viaggi, M. Raggi, Gomez, S. Paloma Farm-household investment behaviour and the CAP decoupling: methodological issues in assessing policy impacts J. Policy Model., 33 (2011), pp. 127-145

Viira, A. Pöder, R. Värnik Discrepancies between the intentions and behaviour of farm operators in the contexts of farm growth, decline, continuation and exit: evidence from Estonia GJAE, 63 (2014), pp. 46-62

Weiss Farm growth and survival: econometric evidence for individual farms in Upper Austria Am. J. Agric. Econ., 81 (1999), pp. 103-116

Weller, E.F. Smith, B. Pritchard Family or Enterprise? What shapes the business structures of Australian farming? Aust. Geogr., 44 (2013), pp. 129-142

Wilson Multifunctional Agriculture: A Transition Theory Perspective CABI, Wallingford (2007)

Wilson From 'weak' to 'strong' multifunctionality: conceptualising farm-level multifunctional transitional pathways J. Rural Stud., 24 (2008), pp. 367-383

Wilson The spatiality of multifunctional agriculture. A human geography perspective Geoforum, 40 (2009), pp. 269-280

Zimmermann, T. Heckelei Structural change of European dairy farms - a cross-regional analysis J. Agric. Econ., 63 (2012), pp. 576-603

Zimmermann, T. Heckelei, I.P. Domínguez Modelling farm structural change for integrated ex-ante assessment: review of methods and determinants Environ. Sci. Policy, 12 (2009), pp. 601-618

${ }^{1}$ SLU is defined as a unit to measure the overall working time requirement of a farm using standardized factors (LBV, Art.3 Abs. 1).

$\stackrel{2}{ }$ Variance inflation factors range from 1.08 (SLU category) to 1.20 (Succession). These values are clearly below the threshold values reported in the literature (O'Brien, 2007).

View Abstract 